\title{
Controlling International Joint Ventures: An Investigation of Australian Parent Partners
}

\author{
Francesco Giacobbe and Peter Booth
}

\begin{abstract}
International joint ventures (IJVs) are an important modern organisational form, with their complexity presenting significant management and control issues. Our research uses a crosssectional survey of Australian parent partners of IJVs to provide insights into the characteristics of Australian companies and their IJVs, performance outcomes and choices of parent partners management control systems (MCS) design in terms of operational areas they seek to control (focus), the extent to which they exercise control (extent) and the mechanisms of control used (formal and informal). Australian parent partners of IJVs generally are; partnering in countries close to Australia in the Asia Pacific, in activities similar to those they undertake in Australia, contributing a significant amount of resources, but overall have only a limited range IJV experience. Australian parent partners focus on a limited set of controls, often with tighter formalised control structures. Finally they are overall satisfied with the performance of their IJVs, with higher satisfaction for organisation learning and product/customer dimensions than financial performance.
\end{abstract}

\section{Correspondence}

Dr Francesco Giacobbe, School of Accounting, University of Technology, PO Box 123, Broadway NSW 2007, Tel: +61 29514 3568, fax: +61 29514 3669, email: francesco.giacobbe@uts.edu.au 
International joint ventures (IJVs) are an important modern organisational form. Multinational corporations use IJVs as a key option for pursuing international strategies (Harrigan 1988; Hergert and Morris 1988; Geringer and Woodcock 1989; Geringer 1991; Parkhe 1993), especially in countries where joint ventures are a regulatory condition of entry to domestic markets (Beamish and Banks 1987; Geringer 1991). From a strategic point of view, IJVs are used to exploit peripheral markets or technologies, and are perceived as critical elements of an organisation's business networks, as strategic weapons for competing within core markets and technologies (Harrigan 1987), and as a way of facilitating interorganisational learning (Buckley and Casson 1988; Hamel 1991; Makhija and Ganesh 1997). In addition, successful IJVs create synergies and enhance economic rents to the partners resulting from risk reduction, economies of scale and scope, production rationalisation, convergence of technologies, and better local acceptance (Harrigan 1988a, 1988b; Hennart 1988; Parkhe 1993). IJVs, therefore, represent an important and effective way for multinational organisations to compete globally (Perlmutter and Heenan 1986).

Pursuing IJV strategies involves significant issues in controlling their venture operations. A parent partner must share control with other partner(s) and face constraints imposed by contractual and legal requirements. Often one partner may enjoy competitive cultural/language advantage and privileged access to information, and may have different (sometime conflicting) interests to the other IJV partner(s) (Anderson 1990; Beamish 1984; Fey 1995; Southworth 1994). Parent partners, therefore, face significant challenges in designing and operating management controls systems able to effectively monitor and control the operations of their IJVs (Anderson 1990; Dolan 1993a, 1993b; Luo 1995).

\section{Inter-organisational Collaboration}

IJVs are one of many forms of inter-organisational networks. Figure 1 summarises the interrelationship of the major factors that may lead to networks as a mean to achieve organisational objectives. In accordance with traditional organisational analysis, an organisation's strategy and objectives are determined by the organisation's own internal resources (strengths and weaknesses) and environmental opportunities and pressures (threats and opportunities). Flexibility in committing scarce resources, risk-sharing, access to critical business resources, increasing environmental complexity, higher degrees of market interrelationships, the emergence of new developing economies and the shift from traditional national markets to global markets are some of the factors that create significant pressures for 
organisations to pursue a strategy of inter-organisational collaboration rather than intraorganisational expansion, and therefore determine the 'Need to network' shown in Figure 1 (Beamish 1988; Schillaci 1988; Contractor and Lorange 1988; Shenkar and Tallman 1993; Mjoen and Tallman 1997).

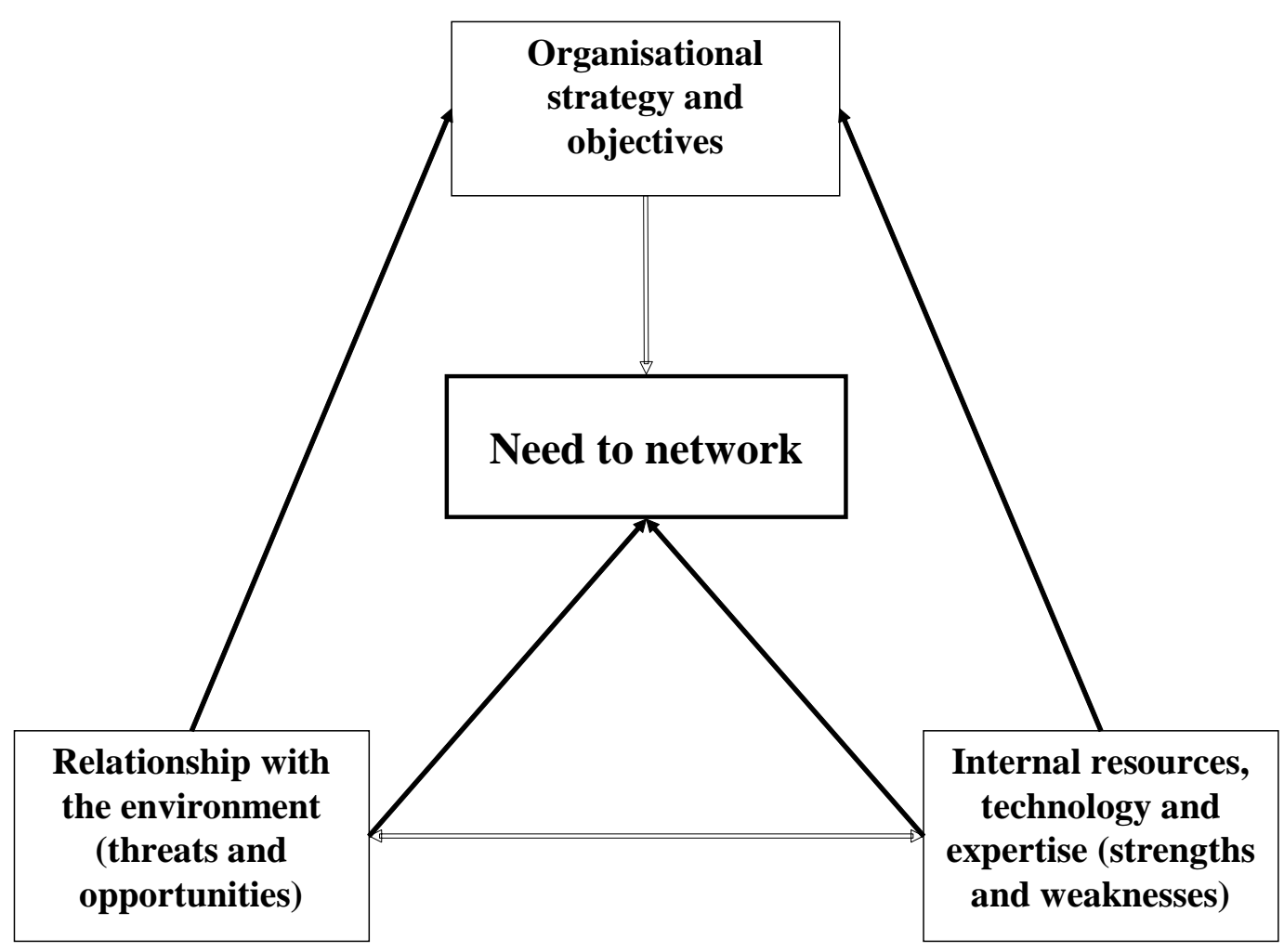

Figure 1 Factors impacting the need to network

There are many forms of networks ranging from informal to formal, short-term to long-term and comprising two or more partners. A joint venture is a form of inter-organisational network where two or more partners enter into an agreement to form a new entity (the JV) to undertake a given set of activities with the aim of achieving agreed objectives. Partners share capital, income, expenditure, profit/losses, management, risk and benefits in accordance with agreed arrangements and proportions.

Historically, the term joint venture was used in the United States (US) to describe a speculative association of firms promoted to undertake very risky projects. With time the speculative nature of the venture became less important and JVs developed as a form of association between firms aimed at undertaking activities (rather than a project) in common (Schillaci 1988). Different characteristics across partners, motives, strategies or objectives, 
different types of projects, characteristics of the operating environment, and the type of resources made available by parent partners are some of the features that give rise to a variety of forms of joint venture collaboration.

In general, the main distinguishing characteristic of JVs is the creation of a separate entity owned by two or more partners who keep their own financial, operational and legal identity and autonomy. Also, the new entity is the result of the parent partners' determination to engage in a collaborative venture, not just an investment. Many motives lead companies to JVs. Often, the motives differ across each partner and on many occasions may even be conflicting. Nevertheless, the decision to form a JV derives from the belief by each partner that despite different/conflicting goals, the benefits of collaboration may outweigh the costs.

JVs can be classified into different types according to their legal or organisational features, location and nature of project/activities. JVs formed by companies originating from the same country, and operating in the same country as the parent partners, are defined as domestic joint ventures. When parent partners' headquarters are located in different countries or the JV has a significant level of operations in more than one country the JV is considered international (Groot and Merchant 2000), which may operate in either developed or developing countries. Table 1 summarises the main characteristics of international and domestic JVs in developed and developing countries.

Domestic JVs in developing countries (Cell III in Table 1) are less frequent and are generally motivated by the need to put together experience and resources to undertake complex and major projects. On the contrary, domestic JVs in developed countries (Cell I) are much more common, where organisations pool their resources and experience to overcome each other's weaknesses and to share risk. Here the partners generally have equal shares (even if one partner may dominate the JV) and the collaboration may last longer.

Table 1Main characteristics of international and domestic JVs

\begin{tabular}{|c|c|c|}
\hline & "Domestic JVs & "International JVs \\
\hline $\begin{array}{c}\text { Developed } \\
\text { countries }\end{array}$ & $\begin{array}{l}\text { Likely to provide for equal } \\
\text { relationship of partners } \\
\text { Longer lasting } \\
\text { Lower level of uncertainty } \\
\text { Lower level of conflict due to } \\
\text { cultural/social barriers } \\
\end{array}$ & $\begin{array}{l}\text { Likely to provide for equal interest of partners } \\
\text { More probability of integration } \\
\text { Likely to be formed to meet increasing global } \\
\text { competition } \\
\text { Greater challenge and uncertainty } \\
\text { Greater cultural/social barriers } \\
\text { II }\end{array}$ \\
\hline
\end{tabular}




\begin{tabular}{||l|l|l||}
\hline & $\begin{array}{l}\text { III } \\
\text { Not very common due to lower } \\
\text { cooperative culture } \\
\text { Used to undertake complex projects } \\
\text { Developing }\end{array}$ & $\begin{array}{l}\text { IVcreasingly developing } \\
\text { Likely to provide for unequal resource contribution } \\
\text { Likely to lead to a de facto dominant partner } \\
\text { Used by foreign partner as a way to enter new } \\
\text { markets } \\
\text { Used by local partner as a way to acquire } \\
\text { knowledge/technology } \\
\text { Greater chance of conflicting goals/objectives. } \\
\text { More likely to be imposed by government } \\
\text { regulation } \\
\text { Greater challenge and uncertainty } \\
\text { Greater cultural/social barriers }\end{array}$ \\
\hline
\end{tabular}

IJVs in developed countries (Cell II) are also quite common and usually motivated by the same reasons as domestic JVs. The acquisition of new markets, use of primary resources and government regulation are additional reasons to form IJVs. Similarly to domestic JVs, partners generally exercise similar levels of control. IJVs between companies originating from developed and developing countries (Cell IV) have increased significantly in recent times. They are often generated by government regulations imposing the JV business structure on international companies wishing to enter developing country markets. In this way it is hoped that local firms may gain experience, transfer knowledge and technology, leading in the medium/long term to independent operations. More significant economic, cultural and social differences are likely to give rise to special control issues in these IJVs. While government regulations may provide for equal legal shares in the joint ventures, actual resource contribution and other factors may determine a de facto dominance by one partner.

A review of the literature suggests that IJVs, similar to other international operations, face greater operational and management challenges than domestic JVs (Groot and Merchant 2000). In addition to the need to 'share' control with other partner(s), parent partners face difficulties in monitoring operations in settings they are not familiar with compounded by physical distance, by time differences, cultural barriers, social barriers, human resource and employee relation differences (Child and Faulkner 1998).

In summary, the above factors all result in greater organisational complexity, making the management of international joint ventures a very challenging task (Child 1991; Child and Markoczy 1993; Beamish 1993). Traditional management control systems, performance evaluation procedures and accounting information used to control and evaluate fully owned subsidiaries or short-term specific project ventures, may not be applicable to international JVs 
(Anderson 1990; Dolan 1993a, 1993b; Luo 1995). There is a need to identify specific issues and investigate factors leading to the successful design, implementation, and operation of efficient and effective management control and performance evaluation systems in international JVs. This study contributes to a better understanding of how foreign parent partners control the operations of their IJVs by reporting the results of an investigation of management control systems of Australian parent partners. In particular, we report how Australian parent partners control the operations of their IJVs with regard to what operational areas they seek to control in relation to their partner(s), their relative influence on the decision-making process in various functional areas and the tools they use to exercise control over their IJVs.

\section{Data Collection}

The results reported in this article were collected in 2005 as part of a larger research project (see Giacobbe (2007) for full details on the research method). The questionnaire was developed following the approach recommended by Dillman (2000). These included the consideration of a set of criteria to select questions to be included in the questionnaire; keeping questions in it as short, simple and clear as possible; constructing the survey questionnaire in a way that would make it easier to understand and answer; providing clear instructions to respondents. Most questions used in the questionnaire were derived and adapted from prior research. In addition, the survey was pilot tested by requesting four managers involved in international JVs, two academics and a manager of a consulting firm to complete the survey questionnaire and provide comments on the relevance and clarity of each question. Their comments were further discussed at face-to-face meetings or through telephone conversations.

The unit of analysis was Australian parent companies of equity JVs operating outside Australia (equity shares in IJVs). Equity JVs were selected because of the inherent clearer definition of rights and obligations and the direct involvement of each partner by introducing resources and bearing the relevant risk. In equity IJVs parent partners acquire equity interest and invest capital and other resources (see Killing 1982, 1983; Groot and Merchant 2000; Yan and Gray 1994).

As a database of Australian parent partners of IJVs was not available, the sample was compiled from a variety of sources: Austrade, financial reports of public companies and databases of Australian companies involved in international business. The final sample 
comprised 439 companies. The total number of returned questionnaires was 99. Two of the questionnaires were not satisfactorily completed, reducing the number of useable completed questionnaires to 97 . The overall response rate was $22.10 \%$. As some respondents did not answer all questions, the number of respondents reported in the following sections may vary.

All respondents were employed at senior managerial levels. The highest percentage of respondents is represented by managing directors (51.58\%), followed by international operations managers (18.95\%). They had been employed by their companies for an average of 11.8 years (Min 1, Max 41), and in their current position for an average of 6 years (Min 0.5, Max 36). Given that respondents have been employed by their companies in senior positions for a significant period of time, it is likely that they had appropriate knowledge and experience about their company’s IJVs and international business involvement.

\section{General Characteristics of Australian Parent Partners}

We report here characteristics of respondent companies and their IJVs.

\section{Parent Partners}

Table 2 shows the size of the respondent companies in terms of number of employees. The companies cover a wide range of sizes, from 2 to 125000 employees. Half of the respondents employ less than 360 people and 71.58\% employ less than 1000 people. This indicates that Australian medium-size companies are actively engaged in IJVs.

Table 2Size characteristics of respondent companies

\begin{tabular}{lccccc}
\hline & Minimum & Maximum & Mean & Std dev. & Median \\
\hline Employees & 2 & 125000 & 3484 & 14056 & 360 \\
\hline Number of employees & Number of companies & \% & Cumulative \% \\
\hline Up to 100 & 27 & 28.42 & 28.42 \\
101 to 1000 & 41 & 43.16 & 71.58 \\
1001 to 10000 & 22 & 23.16 & 94.74 \\
More than 10 000 & 5 & 5.26 & 100.00 \\
\hline
\end{tabular}

Australian parent partners of IJVs are involved in a wide range of business activities. The majority of respondent companies (27.84\%) indicated that their firms are involved in manufacturing activities. Quite prevalent also are mining (15.46\%) and building construction 
companies (8.25\%). Seven companies (7.22\%) are involved in trading activities, six (6.19\%) in primary industry activities other than mining and five companies (5.15\%) provide education services. A significant proportion of Australian companies involved in IJVs operate in a range of services-related industries, including Personal Services (7.22\%), Property and Business Services (6.19\%), Communication (5.15\%), and Financial/Insurance Services (5.15\%). These findings indicate that most Australian companies engage in IJVs production and mining activities where they can contribute know-how, technology and other resources, and take advantage of local business inputs and possibly lower production costs.

Companies pursue a JV strategy for many reasons, including the need to access new markets, resources or technology, share or acquire skills, achieve economies of scale, share risk, minimise the uncertainty of diversification, pool resources to undertake large projects or improve competitiveness, and to comply with government regulation (Schillaci 1988; Hung 1992; Harrigan 1985; Bell 1996). Companies may be motivated by a single or multiple objectives to pursue their strategic business alliances, which may conflict with those of their partners. Different motives may impact on parent partners' management control system choices.

Motives of Australian parent and their foreign partners to JVs are reported in Table 3, ranked in order of importance as rated by the respondents. The results indicate that Australian companies and their international partners are both primarily motivated by profit and growth, but then place different levels of importance to all other motives to JVs. For example, learning is much more important for international parents than Australian parents (motive 3 compared to motive 7). This different pattern of motives is consistent with arguments in the literature that partners of IJVs can have different (and sometimes even conflicting) motives and objectives for the JV.

Table 3Motives

\begin{tabular}{cll}
\hline Rank & \multicolumn{1}{c}{ Australian company } & \multicolumn{1}{c}{ International partner } \\
\hline 1 & Growth & Profit \\
2 & Profit & Growth \\
3 & Expansion to new market & Knowledge exchange/learning \\
4 & Expansion in related products & Risk-sharing \\
5 & Risk-sharing & Expansion in related products \\
6 & Access resources/raw materials & Expansion to new market \\
7 & Knowledge exchange/learning & Expansion through diversification \\
8 & Overcoming government barriers & Access resources/raw materials \\
\hline
\end{tabular}




\begin{tabular}{cll}
\hline 9 & Cost reduction & Co-opting or blocking competition \\
10 & Expansion through diversification & Cost reduction \\
11 & Co-opting or blocking competition & Overcoming government barriers \\
\hline
\end{tabular}

The literature also indicates that motives for entering JVs can have an important influence on parent partners' management control system choices, as both will perceive control as the most critical means of fulfilling their strategic intentions (Anderson 1990; Yan and Gray 1994). The nature of the influence may be determined by a wide range of elements, including the type of specific motives, how a partner's objectives are phrased (for example, financial/nonfinancial), the breadth of partners objectives for the international JV and the fit between international JV's product and the rest of a partner's business (Groot and Merchant 2000). Groot and Merchant (2000), for example, found some evidence of a relationship between parent partner objectives and the choice of focus of control. Franko (1971) found that the type of controls chosen by a parent partner was influenced by the strategy motivating a parent partner to engage in a JV. Specifically, he found that loose controls were used by parent partners of joint ventures resulting from a product diversification strategy, while tighter controls were used by parent partners of JVs to expand the geographical reach of their existing products. Finally, Yan and Gray (1994) found that in the interest of learning, the local (foreign) partner expected from the outset that control would be shifted from the other partner to them over time. The different pattern of JV motives for Australian parents and their international partners, therefore, suggest that Australian IJVs may experience the same issues of different control interests, focus and control system choices between the Australian and international parents.

The experience of companies in international operations and their involvement in other IJVs are often cited as another determinant of management control system choices and as a potential determinant of performance outcomes of IJVs (Child and Yan 2003). It is suggested that companies with more extensive IJV operations experience may be better prepared to deal with the uncertainties and complications of sharing control with others and operating in an unfamiliar (and sometimes unfriendly) environment.

Table 4Australian companies involvement in IJVs

\begin{tabular}{lccc}
\hline Number of IJVs & Number of companies & \% & Cumulative $\%$ \\
\hline 1 IJV & 22 & 22.92 & 22.92 \\
2 to 3 IJVs & 30 & 31.25 & 54.17 \\
\hline
\end{tabular}




\begin{tabular}{llrr}
\hline 4 to 10 IJVs & 33 & 34.38 & 88.54 \\
More than 10 IJVs & 11 & 11.46 & 100.00 \\
\hline
\end{tabular}

Table 4 reports details of Australian companies' involvement in IJVs over the last ten years. The average number of IJVs per surveyed company (9.17) is quite large. However, only $11.46 \%$ have been involved in more than ten IJVs and the majority of companies (54.17\%) have been involved in no more than three IJVs. The findings indicate that the majority of Australian companies involved in IJVs have relatively low experience in international interorganisational collaboration ventures.

\section{IJVs}

We review here characteristics of Australian companies' IJVs. Companies may form IJVs with a single partner or with more than one partner. The majority of respondent's IJVs are with one partner (87.37\%).

Table 5Age of IJVs

\begin{tabular}{lccccc}
\hline & Minimum & Maximum & Mean & Std dev. & Median \\
\hline Age of IJV & 1 & 39 & 6.60 & 6.53 & 4.00 \\
\hline Age of IJV & Companies & \% & Cumulative \% \\
\hline Up to 1 year & 11 & 11.46 & 11.46 \\
2 to 5 years & 45 & 46.88 & 58.33 \\
6 to 10 years & 24 & 25.00 & 83.33 \\
Over 10 years & 16 & 16.67 & 100.00 \\
\hline
\end{tabular}

Table 5 shows the age of IJVs. The average age of IJVs is quite high, 6.53 years. However, the lower value of the median indicates that half of the IJVs were less than four years old and as shown in Table 5, $11.46 \%$ had operated for less than one year. On the other hand, almost $42 \%$ of the IJVs have survived over five years (the longest for 39 years). These findings provide two very important indications. First is that most respondents are involved with mature JVs. Second, the findings suggest good performance for Australian IJVs, given that survival is often used as a key proxy for IJV performance (for example, see Geringer and Herbert 1991; Hatfield et al. 1998). 
Table 6Nationality of partners and area of operations of IJVs

\begin{tabular}{lcc|cc}
\hline & \multicolumn{2}{c|}{ Nationality of partners } & \multicolumn{2}{c}{ Areas of operations of IJVs } \\
\hline Continent/Geographic Area & IJVs & \% & IJVs & \% \\
\hline China & 28 & 29.47 & 25 & 26.32 \\
Rest of Asia & 35 & 36.84 & 37 & 38.95 \\
Pacific & 7 & 7.37 & 16 & 16.84 \\
Europe & 12 & 12.63 & 4 & 4.21 \\
North America & 9 & 9.47 & 2 & 2.11 \\
South America & 1 & 1.05 & 1 & 1.05 \\
Africa & 3 & 3.16 & 3 & 3.16 \\
Global & & & 7 & 7.37 \\
\hline
\end{tabular}

Table 6 reports the nationality of respondents' IJVs partners by continent/geographic areas. As one would expect, Australian companies prefer a JV with partners in nearby countries. The majority of Australian companies IJV's partners are from Asian countries (China alone 29.47\%) and the Pacific region. Next is Europe, followed by North America, Africa and South America. With regard to the areas of IJVs operations, the majority operate in the country of the partner(s), although some exceptions are noticeable, especially for IJVs with European and North American partners operating in Asian and the Pacific areas. In fact, over $80 \%$ of IJVs operate in Asian countries and in the Pacific region while only about $71 \%$ have partners from these geographical areas. Seven IJVs (7.37\%) operate on a global basis. Respondents also indicated that 67 IJVs (69.07\% of the total) operate only in the host country. Respondents indicated that their IJVs are involved in similar activities to those of their Australian parent companies. The majority of IJVs are involved in manufacturing (25.77\%), mining (15.46\%) and construction (10.31\%). Only 14 IJVs (14.43\% of the total) are involved in a business different from their Australian parent partner. Respondents also indicated that 89 IJVs (91.75\% of the total) are involved in a single line of business.

Table 7Level of resource contribution to IJV

\begin{tabular}{lccc}
\hline Type of resource & $\begin{array}{c}\text { Mostly by } \\
\text { Australian } \\
\text { partner (\%) }\end{array}$ & $\begin{array}{c}\text { Shared with } \\
\text { other partner } \\
\text { (\%) }\end{array}$ & $\begin{array}{c}\text { Mostly other } \\
\text { partner (\%) }\end{array}$ \\
\hline Technology & 72.04 & 19.35 & 8.61 \\
Management expertise & 58.06 & 29.03 & 12.91 \\
Material procurement & 40.22 & 15.22 & 44.56 \\
\hline
\end{tabular}




\begin{tabular}{llll}
\hline Marketing skills & 31.46 & 47.19 & 21.35 \\
Customer service skills/facilities & 31.11 & 44.44 & 24.45 \\
Product distribution & 22.47 & 33.71 & 43.82 \\
\hline
\end{tabular}

Australian parent partners provide high levels of resources to their IJVs. The results reported in Table 7 indicate that Australian partners provide significantly higher levels of resources compared to their partner(s) in regard to the provision of technology and management expertise, and slightly higher with regard to marketing and customer services skills. The local partners, instead, make a more significant contribution with regard to product distribution and provision of material inputs.

Provision of critical resources is a strong indicator of a higher level of bargaining power. The literature suggests that bargaining power between partners plays a very important role in shaping parent partner management control system choices (Yan and Gray 1994; Gray and Yan 1992; Mjoen and Tallman 1997; Giacobbe 2007). According to the proponents of bargaining power theory, control of a JV depends on several factors determined by the ability of a partner to bargain with another. Bargaining power factors such as control over critical resources, the availability of alternative partner(s) and the strategic importance of the JV to a partner (stakes) would constitute power bases that can tilt bargaining power in one partner's direction or another (Yan and Gray 1994; Mjoen and Tallman 1997; Giacobbe 2007).

\section{Management Control Systems}

The literature suggests that control of IJVs is a very complex issue. Control of IJVs can be clearly distinguished from domestic operations or fully owned subsidiaries (Anderson 1990; Mjoen and Tallman 1997) and requires special attention.

Parent partners are not free to fully control the operations of their IJVs. The presence of other partner(s) and the 'sharing' principle explicitly or implicitly accepted when it was decided to enter the IJV are significant constraints that limit their ability to exercise control. Geringer and Herbert (1989) provide a very useful model to aid in conceptualising the complex control dynamic of IJVs. They suggest that understanding of parent control in IJVs should consider the following three dimensions:

(1) the focus of control; that is, areas of the operations of IJVs over which parent partners exercise control 
(2) the extent of control; that is, the degree to which parent partners exercise control over the various activities of IJVs

(3) the mechanisms of control; that is, the means by which control is exercised.

Figure 2 is a graphic representation of the model. The model, either in its entirety or with regard to individual dimensions, has been widely used by scholars and researchers when investigating IJVs (for example, see Yan and Gray 1994; Groot and Merchant 2000; Chalos and O’Connor 2004).

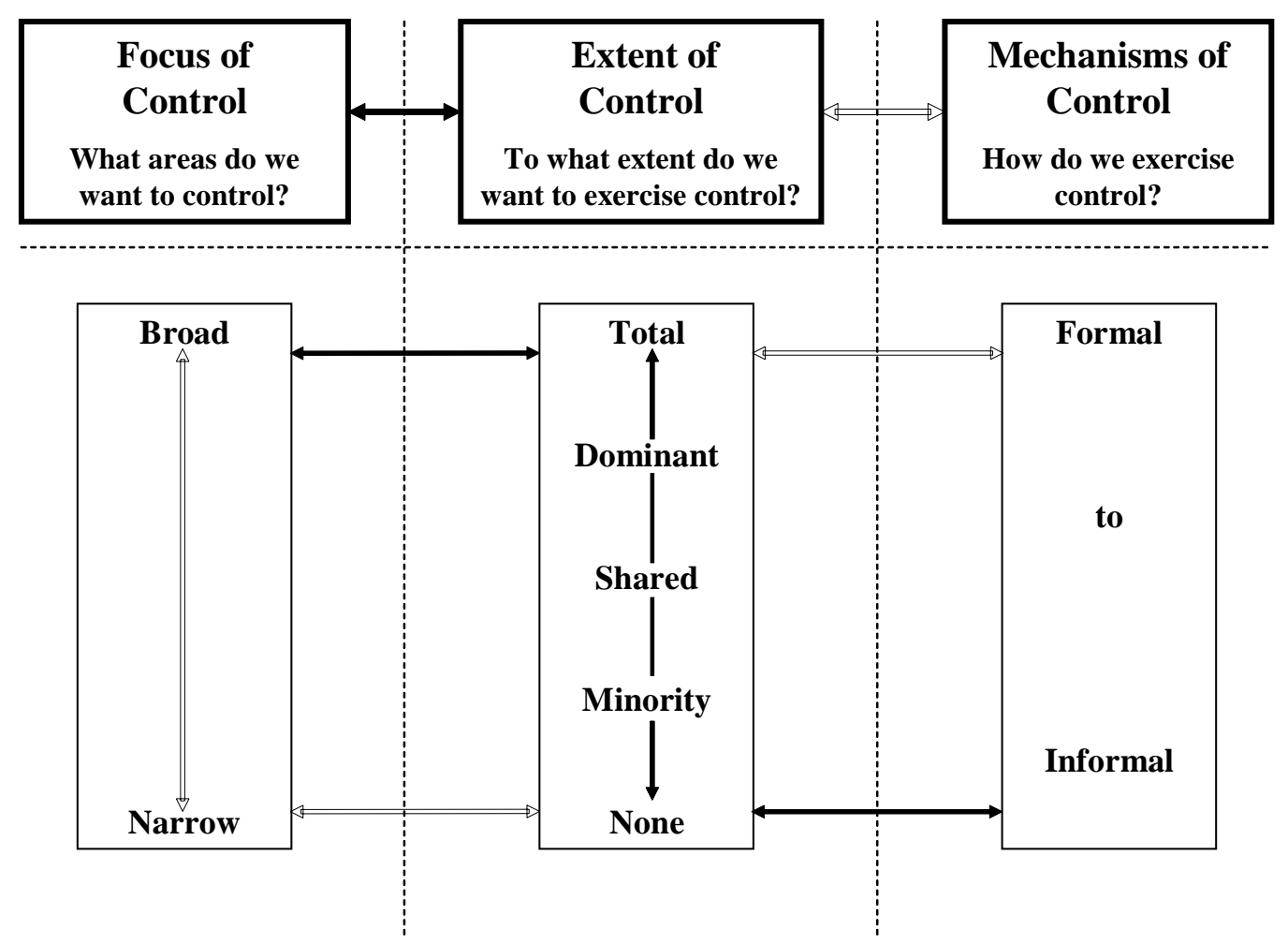

Figure 2 Dimensions of IJVs control

Parent partners must identify and select the operational areas of their IJVs that they wish to attempt to control (Focus of control). Their choice ranges from only a few areas (narrow focus) to a larger set (broad focus). Also, individual partners' ability to influence activities and decisions is limited by the presence of other partner(s). Thus, for each operational area individual partners may be able to exercise control on a continuum from 'none' to 'total' control (Extent of control). Finally, partners have choice as to the mechanisms of control, ranging from formal to informal, that they can seek to deploy to achieve the desired focus and extent of control. 
Many factors may determine the actual ability of a parent partner to exercise control, including the level of trust in the other partner(s), motives for entering the JV, relative resources contribution, relative bargaining power and a partner's international experience (Groot and Merchant 2000; Yan and Gray 1994; Giacobbe 2007).

We now briefly review the three dimensions and report Australian parent partners' assessment of management control systems aimed at monitoring their IJVs operations.

\title{
Focus of Control
}

According to Groot and Merchant (2000, p. 586):

\begin{abstract}
Partners can choose to have a broad control focus and attempt to exercise control over the entire range of the IJV's activities, or they can have a narrow focus and confine their control activities to the few activities or performance dimensions they consider most critical.
\end{abstract}

A parent partner's selection of a range of operational areas of their IJVs to control has significant implications on the design and implementation of relevant management control systems. Choices are influenced by many factors limiting the ability of a parent partner to exercise total absolute control over all activities of an IJV. The presence of other partner(s), limited resources, expertise, power relationships, contingent factors and management of the relationship with other partner(s) are only some examples of these constraints. Empirical studies confirm the general inability of a parent partner to exercise exclusive and total control over all activities (Schaan 1988; Schaan and Beamish 1988; Geringer and Herbert 1989, 1991; Yan and Gray 1994, 2001; Groot and Merchant 2000; Giacobbe 2007). Thus there is a need for parent partners to select areas of the IJVs' operations they wish to control.

Table 8Managers provided to the IJV in the last five years

\begin{tabular}{lccc}
\hline Functional areas & $\begin{array}{c}\text { More than } \\
\text { our } \\
\text { partner(s) } \\
\mathbf{( \% )}\end{array}$ & $\begin{array}{c}\text { The same as } \\
\text { our } \\
\text { partner(s) } \\
\mathbf{( \% )}\end{array}$ & $\begin{array}{c}\text { Less than } \\
\text { our } \\
\text { partner(s) } \\
\mathbf{( \% )}\end{array}$ \\
\hline Revenue and cost budgeting & 51.11 & 27.78 & 21.11 \\
Development of new products/services & 50.00 & 27.91 & 22.09 \\
Management of daily operations & 44.57 & 27.17 & 28.26 \\
Capital expenditure approval & 38.89 & 41.11 & 20.00 \\
Finance management & 32.97 & 42.86 & 24.17 \\
General administration & 28.57 & 34.07 & 37.36 \\
Human resources management & 26.67 & 37.78 & 35.55 \\
\hline
\end{tabular}




\begin{tabular}{llll}
\hline Pricing policy & 26.44 & 47.12 & 26.44 \\
Public/government relations & 24.18 & 21.98 & 53.84 \\
Marketing and distribution & 22.73 & 37.50 & 39.77 \\
\hline
\end{tabular}

A key indicator of the focus of control exercised by Australian parent partners is the number of managers relative to the international partner(s) provided to the IJV over the last five years in major functional areas. The results are reported in Table 8.

On average, Australian parent partners provided a larger number of managers than their international partners in planning and operational functions. These are the areas where they also make a more significant contribution of resources (see Table 7). In general, however, both partners appear to provide a significant number of managers in all other functional areas. This finding suggests that Australian parent partners may seek a relatively narrow focus of control.

Other indicators of focus of control could be inferred from the composition of the JV board or management committee, and the right to appoint the IJV's general manager.

Table 9 reports on composition of IJVs board/management committees. Most IJVs share equal proportions of board/management committee membership; however, more Australian companies are in a minority position than those in a majority position.

Table 9IJVs board composition

\begin{tabular}{lcc}
\hline Australian parent (\%) & IJVs & \% \\
\hline Less than 50 & 31 & 32.98 \\
50 & 43 & 45.74 \\
More than 50 & 20 & 21.28 \\
\hline
\end{tabular}

Table 10 reports on the right to appoint the IJV's general manager. The findings indicate that Australian partners are solely entitled to appoint the general manager in $35.05 \%$ of cases. This percentage is higher than the corresponding right of the local parent partner(s).

Table 10 Appointment of IJVs' general manager

\begin{tabular}{lcc}
\hline IJV general manager appointed by: & IJVs & \% \\
\hline Australian-based partner & 34 & 35.05 \\
Mutual agreement with other partner(s) & 32 & 32.99 \\
Other partner(s) & 23 & 23.71 \\
\hline
\end{tabular}




\begin{tabular}{lll}
\hline In rotation with other partner & 6 & 6.19 \\
Other & 2 & 2.06 \\
\hline
\end{tabular}

Table 11 reports the right to appoint the IJVs general manager in three sub-groups of respondents sorted according to the position of the Australian partner in the IJVs' board/management committee; minority, equal or majority. The data show that Australian parent partners, in general, are entitled to appoint more general managers to their IJVs than respective foreign partners when in either a position of majority or minority. More specifically, when in a majority position Australian partners appoint 80\% of their IJV's general managers, while their foreign partners in a majority position do the same in $25.81 \%$ of cases. Similarly, when in a position of minority, Australian partners have the right to appoint general managers in $19.35 \%$ of cases while their partners do so in $5 \%$ of cases.

Table 11 Appointment of IJV's general manager and IJV board composition

\begin{tabular}{lrrr}
\hline & \multicolumn{4}{c}{ Australian partner position in IJV board } \\
Minority & Equal & Majority \\
IJV general manager appointed by: & (\%) & (\%) & (\%) \\
\hline Australian-based partner & 19.35 & 27.91 & 80.00 \\
Mutual agreement with other partner(s) & 51.61 & 30.23 & 10.00 \\
Other partner(s) & 25.81 & 30.23 & 5.00 \\
In rotation with other partner & 3.23 & 9.30 & 5.00 \\
Other & 0.00 & 2.33 & 0.00 \\
\hline
\end{tabular}

\section{Extent of Control}

The concept of extent of control stems from organisational behaviour research and it refers to the centralisation or the locus of decision-making. Extent of control could be conceptualised as a dichotomous absolute variable (that is, total parent control or no control at all) or as a continuous variable (that is, dominant, shared or minority levels of control exercised over different strategically important activities). The literature indicates support for the conceptualisation of control as a continuous rather than a dichotomous variable (Groot and Merchant 2000; Yan and Gray 1994; Giacobbe 2007).

Parent partners may therefore exercise control over selected operational areas (focus) on a continuum from minority to total (extent). Their ability to set the extent of control is determined by factors similar to those influencing control focus, including the strategic importance attached to various areas of operations of their IJVs and the relative bargaining 
power with other partner(s). Other factors that may determine the extent of control include parent partners' superior knowledge of business processes and other operational aspects, ownership of technology and critical resources, which may determine a de facto total control position.

The extent of control is indicated via the relative influence exercised by parent companies over the same set of IJV's functional areas considered for focus of control. The results are reported in Table 12.

Table 12 Relative influence in the decision-making process of your IJV

\begin{tabular}{lccc}
\hline Functional areas & $\begin{array}{c}\text { More than } \\
\text { our } \\
\text { partner(s) }\end{array}$ & $\begin{array}{c}\text { The same as } \\
\text { our } \\
\text { partner(s) }\end{array}$ & $\begin{array}{c}\text { Less than } \\
\text { our } \\
\text { partner(s) }\end{array}$ \\
\hline Capital expenditure approval & 51.14 & 38.64 & 10.22 \\
Marketing and distribution & 50.00 & 39.13 & 10.87 \\
Management of daily operations & 45.16 & 27.96 & 26.86 \\
Human resources management & 42.39 & 44.57 & 13.04 \\
General administration & 40.66 & 42.86 & 16.48 \\
Pricing policy & 35.87 & 36.96 & 27.17 \\
Finance management & 31.52 & 41.30 & 27.18 \\
Public/government relations & 27.17 & 16.30 & 56.53 \\
Revenue and cost budgeting & 26.97 & 53.93 & 19.10 \\
Development of new products/services & 25.84 & 49.44 & 24.72 \\
\hline
\end{tabular}

Australian parent partners exercise greater relative influence over a large number of functional areas of their IJVs, although in many cases they appear to share the decisionmaking process with the local partners. 'Public and government relations' is the operational area where local partners exercise a more significant extent of control.

In general, the findings suggest that Australian partners exercise a greater extent of control than their local partner(s) over a wider range of operational areas than those indicated as part of their focus of control. This may be a consequence of superior knowledge and/or ownership of critical business resources by the Australian parent partner. 


\section{Mechanisms of Control}

Mechanisms of control are tools used to exercise control ranging from strict rules and regulations to social activities. Research on management control systems suggests many different classifications of mechanisms of controls and we now briefly review some relevant to IJVs.

Yan and Gray $(1994,2001)$ suggest that controls may be broken down into strategic, structural and operational. Strategic controls aim to determine and monitor goals, strategies and objectives of IJVs. Structural controls refer to the degree of autonomy allowed by parent partners to IJV management (that is, the extent to which the venture is authorised to operate as an autonomous unit). Operational controls refer to controlling everyday operations of the IJV.

Bartlett (1986) suggests that mechanisms of control can be broken down into three groups. The first refers to context-oriented mechanisms; informal and culture-based controls aimed at establishing an organisational context. Examples may be emphasising teamwork rather than a you and us approach, or identifying staff as IJV's employees rather than parent partners' representatives. Content-oriented mechanisms are the second group and refer to direct intervention of parent partners through the IJV's top management and board of directors. The third group includes process-oriented mechanisms. These mechanisms allow parents to exercise control from a distance, through the use of reporting requirements and indirect influence over the planning and decision-making process. Accounting procedures and performance measurement would be included in this group. Obviously, both formal and informal mechanisms of control form part of each group (and may be worthy of a separate classification).

Groot and Merchant (2000) suggest classifying control mechanisms according to the object of control and to adopt Merchant's (1998) classification of actions, results, and personnel/cultural controls. Parent partners could exercise action controls by imposing rules and procedures aimed, for example, at preserving assets, limiting decision-making and prohibiting the undertaking of certain courses of action. Results controls refer to mechanisms aimed at monitoring whether goals and objectives are being met, and may include performance evaluation and performance-related rewards and punishment mechanisms. Personnel and cultural controls include socialisation and peer control mechanisms aimed at encouraging positive performance. 
Makhija and Ganesh (1997) classify control categories on a continuum ranging from highly formal to highly informal on the basis of the type of knowledge each partner seeks. They suggest that:

The more predictable, regular, and explicit the information to be transferred, the more formal and structural the relevant controls are likely to be. In contrast, the more uncertain, ambiguous, and organizationally embedded the information, the more informal the controls will be. (p. 517)

Fryxell et al. (2002) also distinguish mechanisms of control in a similar way as formal and social. Formal mechanisms include two groups: cybernetic and those aimed at protecting the assets of parent companies. These control mechanisms have two aims. The first is to detect behaviour and deal with this in a timely manner. The second is to reduce the potential for opportunistic use of resources contributed by a parent partner to the IJV. The authors indicate that mechanisms involving hierarchy, planning and reporting best fit in this group. Social mechanisms of control, instead, are designed to permit the '...evolution and inculcation of norms and values through structured personal interaction and training' (Fryxell et al. 2002, p. 869).

Fryxell et al. (2002) suggest that social control mechanisms can be very powerful as they ultimately give rise to ethical norms and behaviours that determine the most correct way of operating. Their aim is prevention through promoting cultural blending between managers achieved by socialisation processes and training involving the IJV as a whole.

In summary, there are many classifications and definitions of control mechanisms. All exhibit significant similarities and where they differ; in fact, often complement each other. For example, the Fryxell et al. (2002) classification includes most of Merchant's (1998) actions and results controls as part of formal mechanisms of control and most personnel and cultural controls as part of social mechanisms of control.

In this survey we adopted the two broad categories of mechanisms of control suggested by Fryxell et al. (2002) relabelled as:

(1) formal bureaucratic control mechanisms

(2) social promotive control mechanisms.

Table 13 Use of formal bureaucratic mechanisms of control 


\begin{tabular}{lccc}
\hline & $\mathbf{( \% )}$ & $\mathbf{( \% )}$ & $\mathbf{( \% )}$ \\
\hline Planning and budgeting & 79.12 & 14.29 & 6.59 \\
Formal authority relationship & 68.48 & 17.39 & 14.13 \\
Standardised procedures and rules & 68.13 & 18.68 & 13.19 \\
Supervision & 58.70 & 27.17 & 14.13 \\
Contracts & 50.55 & 25.27 & 24.18 \\
Performance evaluation & 42.86 & 38.46 & 18.68 \\
Structural grouping and departmentalisation & 31.87 & 28.57 & 39.56 \\
\hline
\end{tabular}

The results shown in Table 13 indicate high reliance of Australian parent partners on formal bureaucratic controls. Of particular interest is the frequent use of planning and budgeting ('Used Often' by $79.12 \%$ of respondents), formal authority relationships (68.48\%), and standardised procedures and rules (68.13\%). These suggest that despite the high level of environmental uncertainty typical of foreign operations, Australian parent partners choose to use a highly structured approach to control.

Australian parent partners also rely, but to a lower extent, on the use of social and promotive mechanisms of control. The results reported in Table 14 indicate a higher reliance on people controls (meetings, groups, networking) than cultural controls (rituals, traditions and ceremonies).

Table 14 Use of social promotive mechanisms of control

\begin{tabular}{lccc}
\hline Mechanism of control & $\begin{array}{c}\text { Used often } \\
\text { Used } \\
\text { sometimes } \\
\mathbf{( \% )}\end{array}$ & $\begin{array}{c}\text { Not used } \\
\mathbf{( \% )}\end{array}$ \\
\hline Meetings and organised personal contact & 63.74 & 24.18 & 12.09 \\
Networking and other socialisation processes & 45.05 & 25.27 & 29.67 \\
Teams and taskforces & 36.26 & 28.57 & 35.16 \\
Transfer of managers/lateral movements & 24.18 & 29.67 & 46.15 \\
Rituals, traditions and ceremonies & 16.48 & 31.87 & 51.65 \\
\hline
\end{tabular}

In summary, the results of this study indicate that Australian parent partners choose a narrower control focus, but exercise a greater extent of control over a wider set of activities by relying on more extensive use of formal mechanisms of control. 


\section{Parent Partner Influence on Design of Control System}

The literature indicates that the management and corporate style of parent partners may influence the set-up of their IJVs management control systems, with parent partners preferring features perceived to be similar to their own control systems (Groot and Merchant 2000; Firth 1996). Parent partners perceiving similarities between the control of IJVs and control of their own operations may feel more confident with the working of the IJV control system, therefore adopting a more relaxed attitude towards the venture and their partner(s). Our investigation reveals that most respondents ( $72.16 \%$ of the total) feel that the management control system of their IJVs is similar to that of their company. Only $13.40 \%$ of respondents feel their IJVs' management control system was different.

\section{IJV Performance}

The literature indicates that evaluating the performance of IJVs is a very complex issue as these ventures operate in complex, unfamiliar and unpredictable environments (Anderson 1990). Thus there is a need to consider the use of a wide range of performance indicators able to link an organisation's strategic determinants and its performance, incorporating accounting and market-based (Seth 1990), financial and non-financial performance measures.

Geringer and Herbert (1991) note that efforts to identify variables associated with IJV performance have been constrained by disagreement concerning appropriate performance measures and methods. Reviewing the relevant literature, they indicated that some early studies used financial indicators such as profitability, growth and cost position, while others used objective measures of performance such as survival, duration, instability of ownership and renegotiations of JV contracts.

Geringer and Herbert (1991) argue that objective financial measures of performance may not always be appropriate because most of the relevant information and data are not reported or published as returns from JVs to parents, which are generally internal and, in some cases, not able to be measured in financial terms. Subjective measures (qualitative factors) may be preferable, but due to their inherent limitation (subjectivity), they may not always produce correct results. The authors therefore tested several hypotheses regarding the reliability and comparability of a range of subjective and objective measures of IJV performance, and evaluated the relative utility of different data collection approaches. They found that objective measures were positively correlated with parent firms' reported satisfaction with IJVs' 
performance and with perceptions of the extent to which an IJV performed relative to its initial objectives. The evaluation of the venture's performance by one parent partner was also found to be strongly correlated to that of the other partner and to that of the management of the IJV itself. Thus, Geringer and Herbert (1991) concluded that:

(1) in the absence of other performance data the use of subjective measures as reliable performance surrogates may be justifiable

(2) it is appropriate to use a single parent company respondent for collecting performance data.

In this survey we used a subjective assessment of IJV's performance by asking respondents to indicate both their level of satisfaction with the overall performance of the IJV and the degree of satisfaction with the achievement of specific performance outcomes. The results are reported in Table 15.

The performance outcomes cover a wide range of criteria that we grouped into three broad categories: learning performance, product/customer performance, and financial performance.

Table 15 Degree of satisfaction with IJV performance

\begin{tabular}{llcc}
\hline Performance domains & $\begin{array}{c}\text { Satisfied } \\
\mathbf{( \% )}\end{array}$ & $\begin{array}{c}\text { Neither } \\
\text { satisfied nor } \\
\text { dissatisfied } \\
\mathbf{( \% )}\end{array}$ & $\begin{array}{c}\text { Dissatisfied } \\
\text { (\%) }\end{array}$ \\
\hline Overall IJV performance & $\mathbf{7 7 . 3 2}$ & $\mathbf{1 3 . 4 0}$ & $\mathbf{9 . 2 8}$ \\
\hline Specific performance outcomes & & & \\
\hline Learning performance & & & \\
Harmony with other partner(s) & $\mathbf{7 2 . 5 0}$ & $\mathbf{1 7 . 4 9}$ & $\mathbf{1 0 . 0 2}$ \\
Ability to adapt to new environment & 82.02 & 14.61 & 3.37 \\
Morale of people involved with IJV & 74.16 & 16.85 & 8.99 \\
Learning about unfamiliar markets & 72.22 & 16.67 & 11.11 \\
Ability to adopt innovation & 75.64 & 12.82 & 11.54 \\
Learning about new technology & 68.24 & 21.18 & 10.59 \\
Product/customer performance & 61.54 & 23.08 & 15.38 \\
Product/service quality & $\mathbf{7 0 . 6 9}$ & $\mathbf{2 2 . 0 5}$ & $\mathbf{7 . 2 5}$ \\
Product/service cost & 76.47 & 18.82 & 4.71 \\
Customer satisfaction & 71.76 & 21.18 & 7.06 \\
\hline
\end{tabular}




\begin{tabular}{lccc}
\hline IJV product/service price & 62.50 & 26.25 & 11.25 \\
Financial performance & $\mathbf{6 0 . 4 3}$ & $\mathbf{2 5 . 5 9}$ & $\mathbf{1 3 . 9 8}$ \\
Productivity & 72.53 & 19.78 & 7.69 \\
Financial resources indicators & 61.63 & 27.91 & 10.47 \\
Market share & 62.34 & 22.08 & 15.58 \\
Profit & 53.57 & 27.38 & 19.05 \\
Cash flow & 51.19 & 30.95 & 17.86 \\
\hline
\end{tabular}

Overall, 77\% of respondents perceive that their IJVs have performed satisfactorily, which is consistent with the mature nature of the IJVs reported in this survey, as it would be expected that high levels of dissatisfaction would led to IJV termination. In terms of specific performance outcomes for all dimensions, over 50\% of respondents indicated their company was satisfied with the performance of their IJVs. Also, the overall level of dissatisfaction was low for each outcome. The highest satisfaction was with learning performance and the lowest with financial performance, consistent with other results reported in the literature. Finally, market share, profit and cash flow are the areas of lowest satisfaction and highest dissatisfaction, which were the most important motives for engaging in IJVs (see Table 3). Thus, while respondents were satisfied with IJV performance, it would be inferred that their performance aspirations were not fully met.

\section{Summary and Conclusion}

In this study we have reported the results of a survey of Australian parent partners of IJVs. The survey collected data on general characteristics of Australian parent partners, their IJVs, their management control system choices and parent partners' assessment of their IJVs' performance outcomes. Geringer and Herbert's (1989) dimensions of control model was used to investigate parent partner control of IJVs. The model suggests that parent partners are not free to totally control their IJVs and therefore choose operational areas they wish to control (focus of control), the extent to which they may control each operational area (extent of control) and how they exercise control (mechanisms of control).

The results indicate that the majority of Australian companies have partners from countries close to Australia in Asia and the Pacific area, most IJVs operate in the country of their partner(s), and operations are usually limited to the host country. A significant implication of these findings is that IJVs of Australian companies are likely to operate in developing 
countries/geographical areas where higher levels of environmental uncertainty and greater probability of conflicting interests with other partner(s) may generate special control issues.

Australian companies engaged in IJVs have limited involvement in other IJVs. The literature suggests that experience may be a significant factor aiding parent companies with the complexities of sharing management and control with other partners, especially when operating overseas. Additional learning deriving from involvement in IJVs may allow a parent partner to better assess potential problems and make more relevant management control system choices, which, in turn, may impact on the success of new IJVs. As a substitute for direct experience, learning from the experience of others may also aid in this regard.

The results indicate that the IJVs of Australian companies are involved in activities similar to those of their Australian parent partners, which contribute a significant amount of resources to their IJVs. These findings indicate that Australian parent partners may enjoy a superior knowledge of business processes and use of relevant technology, perhaps offsetting any disadvantages flowing from a relative lack of experience with the complexities of IJV management. Australian parent partners therefore may be positioned to better control relevant operational areas of their IJVs. On the other hand, their foreign partners may wish to take advantage of this knowledge by seeking control systems able to facilitate knowledge transfer and learning giving rise, thus, to shifting power positions over time.

Similar motives drive Australian companies and their foreign partners to engage in JVs, however, with different degrees of importance. While profit and growth are important to both, motives related to knowledge acquisition are rated higher by the international partners. The literature indicates that different types of motives and, sometimes, conflicting objectives between partners may significantly impact on parent partners' management control system choices (Giacobbe 2007) and on performance outcomes (Wakefield and Giacobbe 2008). Conflicting motives may place a heavy burden in selecting control systems. Each partner may be pushing for control of operational areas they feel are more strategically important to their motives and seek a degree of control and/or mechanisms able to aid in the achievement of their objectives. As noted earlier, transfer of technology and business processes knowledge may be a significant motive of many foreign partners of Australian companies. Over time, as the foreign partner acquires relevant knowledge, the initial advantage enjoyed by the Australian parent partners may be reduced giving rise to new power relationships and consequent de facto control of the IJVs operations. 
Choosing the correct partner and, most importantly, managing and maintaining good relationships in the IJV are very important factors that may significantly impact on management control system choices and the long-term survival of the business venture.

With regard to Australian parent partners management control systems aimed at monitoring their IJVs, most respondents feel that systems in place in their IJVs are similar to those used by their company. Australian partners provide more managers than their partner(s) in a limited number of their IJVs' functional areas, but exercise significant influence over the decision-making processes of a larger set of functional areas. These indications suggest a narrower focus and greater extent of control. Australian parent companies use formal bureaucratic mechanisms of control more frequently than informal social promotive mechanisms of control.

In general, respondents indicated satisfaction with the performance of their IJVs, although a higher level of satisfaction was reported for learning and product/customer performance dimensions than for financial performance. Little evidence is available in the literature on factors that may significantly impact on performance outcomes of IJVs. Suggestions from research indicate that parent partners exercising narrower control focus, more dominant control extent and tighter formal control mechanisms show a higher degree of satisfaction with their IJVs performance outcomes (Giacobbe 2007).

Overall, the results of the survey indicate two major features of how parent partners control successful IJVs. The first deals with the selection of objects of control (focus of control) and the second with actual exercise of control (extent and mechanisms).

Australian parent partners focus only on a limited set of control objects. They adopt a narrow control focus. This may be due to a number of factors. Objective factors such as the physical distance from the location of their IJVs and the lack of experienced managers are likely to have a significant effect in this regard. However, as noted earlier Australian companies are likely to enjoy a higher bargaining power to that of their foreign partners due to their superior knowledge of business processes and ownership of technology leading to de facto control of their IJVs. Australian parent partners may therefore seek to formally control a narrower set of their IJV operational areas. On the other hand, the foreign partner may seek formal control over a wider range of operational areas to facilitate knowledge and technology transfer.

The second feature deals with extent and mechanisms of control. The results suggest that Australian parent partners seek tighter formalised structures. This is an indication of greater 
extent of control achieved by using more formal bureaucratic methods. It could be argued that these choices may counter the limitations of narrow focus of control. Despite Australian parent partners formally controlling only a limited set of activities, they seek de facto dominant decision-making power in a wide range of strategically important functional areas, protecting, therefore, their overall interest in the venture.

These findings are similar to those reported in the literature on management control systems used to control operations in international and inter-organisational settings (Pangarkar and Klein 2004; Mjoen and Tallman 1997; Fryxell et al. 2002). Cultural differences, geographical distance and the need to share information and decision-making with other partner(s) may limit the ability of parent partners to control a broader range of functional areas of their IJVs and require them to seek more formal and tighter controls over a limited set of control objects. Effective and efficient control is not limited to only one of Geringer and Herbert's (1989) dimensions of IJVs control, but involves decisions and choices on each of the three dimensions, which may be affected by several factors including choosing the right partner, strategic motives, bargaining power, and the parent partner's experience and involvement in other international joint ventures (Giacobbe 2007; Yan and Gray 1994; Groot and Merchant 2000). A better understanding of these and other factors that may determine management control systems choices should be of great interest to practitioners and companies involved in international and inter-organisational operations.

The results of this study provide important indications for companies involved in IJVs or planning to implement such a strategy. Controlling IJVs is always a challenge, both for experienced and inexperienced parent partners. The results of the survey provide interesting information on the characteristics of Australian parent partners of IJVs, their choices of management control systems and their IJV performance outcomes. Throughout this article, we have referred to indications of published research and put forward suggestions on potential factors that may influence parent partners' management control systems choices and may impact on their IJV performance.

Dr Francesco Giacobbe is in the School of Accounting, University of Technology, Sydney, and Professor Peter Booth is the Senior Deputy Vice-Chancellor of the University of Technology, Sydney. 


\section{References}

Anderson, E. 1990, 'Two Firms, One Frontier: On Assessing Joint Venture Performance', Sloan Management Review, 31 (2): 19-30.

Bartlett, C.A. 1986, 'Building and Managing the Transnational: The New Organisation Challenge', in M. Porter (ed.), Competition in Global Industries, Harvard Business School Press, Boston, pp. 367-404.

Beamish, P.W. 1988, Multinational Joint Ventures in Developing Countries, Routledge, London.

Beamish, P.W. 1993, 'Characteristics of Joint Ventures in the People’s Republic of China', Journal of International Marketing, 1 (1): 29-48.

Beamish, P.W. 1984, Joint Venture Performance in Developing Countries, unpublished Doctoral Dissertation, University of Western Ontario.

Beamish, P.W. and Banks, J.C. 1987, 'Equity Joint Ventures and the Theory of the Multinational Enterprise', Journal of International Business Studies, 18 (2): 1-16.

Bell, J. 1996, Single or Joint Venturing?, Ashgate Publishing Limited, Aldershot.

Buckley, P.J. and Casson, M. 1988, 'A Theory of Co-Operation in International Business', Management International Review, 28: 19-38.

Chalos, P. and O'Connor, N.G. 2004, 'Determinants of the Use of Various Control Mechanisms in US-Chinese Joint Ventures' Accounting, Organizations and Society, 29 (7): 591-608.

Child, J. 1991, 'A Foreign Perspective on the Management of People in China', International Journal of Human Resources Management, 2 (1): 93-107.

Child, J. and Faulkner, D. 1998, Strategies of Co-operation: Managing Alliances, Networks, and Joint Ventures, Oxford University Press, Oxford.

Child, J. and Markoczy, L. 1993, 'Host-Country Managerial Behaviour and Learning in Chinese and Hungarian Joint Ventures’, Journal of Management Studies, 30 (4): 611-31.

Child, J. and Yan, Y. 2003, 'Predicting the Performance of International Joint Ventures: An Investigation in China', Journal of Management Studies, 40 (2): 283-320.

Contractor, F.J. and Lorange, P. 1988, Cooperative Strategies in International Business: Joint Ventures and Technology Partnerships between Firms, Lexington Books, Lexington.

Dillman, D.A. 2000, Mail and Internet Surveys - The Tailored Design Method, John Wiley \& Sons, New York.

Dolan, D.K. 1993a, 'Special Issues in Structuring International Joint Ventures - Part One', Tax Management International Journal, 22 (2): 51-63.

Dolan, D.K. 1993b, 'Special Issues in Structuring International Joint Ventures - Part Two', Tax Management International Journal, 22 (3): 103-117.

Fey, C.F. 1995, 'Important Design Characteristics for Russian-Foreign Joint Ventures', European Management Journal, 13 (4): 405-15.

Firth, M. 1996, 'The Diffusion of Managerial Accounting Procedures in the People's Republic of China and the Influence of Foreign Partnered Joint Ventures', Accounting Organizations and Society, 21 (7/8): 629-54. 
Franko, L.G. 1971, 'Multinational Ventures: Divorce-American Style', Management Review, 60 (9): $45-7$.

Fryxell, G.E., Dooley, R.S. and Cryza, M. 2002, 'After the Ink Dries: the Interaction of Trust and Control in US-based International Joint Ventures', Journal of Management Studies, 39: 865-86.

Geringer, J.M. and Herbert, L. 1989, 'Control and Performance of International Joint Ventures’, Journal of International Business Studies, 20 (2): 235-54.

Geringer, J.M. and Herbert, L. 1991, 'Measuring Performance of International Joint Ventures', Journal of International Business Studies, 22 (2): 249-63.

Geringer, J.M. 1991. 'Strategic Determinants of Partner Selection Criteria in International Joint Ventures’, Journal of International Business Studies, 22 (1): 41-62.

Geringer, J.M. and Woodcock, P. 1989, 'Ownership and Control of Canadian Joint Ventures', Business Quarterly, 54 (1): 97-105.

Giacobbe, F. 2007, Controlling International Joint Ventures from a Distance, Unpublished Doctoral Dissertation, University of Technology, Sydney.

Gray, B. and Yan, A. 1992, 'A Negotiations Model of Joint Venture Formation, Structure and Performance: Implications for Global Management', Advances in International Comparative Management, 7: 41-75.

Groot, T.L.C.M. and Merchant, K.A. 2000, 'Control of International Joint Ventures', Accounting, Organizations and Society, 25 (6): 579607.

Hamel, G. 1991, 'Competition for Competence and Inter-partner Learning Within International Strategic Alliances’, Strategic Management Journal, 12: 83-103.

Harrigan, K.R. 1985, Strategies for Joint Ventures, Lexington Books, Lexington.

Harrigan, K.R. 1987, 'Strategic Alliances: Their New Role in Global Competition', Columbia Journal of World Business, 22 (2): 67-9.

Harrigan, K.R. 1988a, 'Joint Ventures and Competitive Strategy', Strategic Management Journal, 9 (2): 141-58.

Harrigan, K.R. 1988b, 'Strategic Alliances and Partner Asymmetries', Management International Review, 28: 53-72.

Hatfield, L., Pearce, J.A. II, Sleet, R.G. and Pitts, M.W. 1998, 'Toward Validation of Partner Goal Achievement as a Measure of Joint Venture Performance', Journal of Management Issues, 10 (3): 355-72.

Hennart, J.F. 1988, ‘A Transaction Costs Theory of Equity Joint Ventures', Strategic Management Journal, 9 (4): 361-74.

Hergert, M. and Morris, D. 1988, 'Trends in International Cooperative Agreements', in Contractor, F. and Lorange, P., Cooperative Strategies in International Business, Lexington Books, Lexington.

Hung, C.L. 1992, 'Strategic Business Alliances between Canada and the Newly Industrialized Countries of Pacific Asia’, Management International Review, 32 (4): 345-61.

Killing, J.P. 1982, 'How to Make a Global Joint Venture Work', Harvard Business Review, 60 (3): 120-7.

Killing, J.P. 1983, Strategies for Joint Venture Success, Praeger, New York. 
Luo, Y. 1995, 'Business Strategy, Market Structure, and Performance of International Joint Ventures: The Case of Joint Ventures in China', Management International Review, 35 (3): 241-64.

Makhija, M.V. and Ganesh, U. 1997, 'The Relationship Between Control And Partner Learning In Learning-related Joint Ventures’, Organisation Science, 8 (5): 508-27.

Merchant, K.A. 1998, Modern Management Control Systems: Text and Cases, Prentice Hall, New Jersey.

Mjoen, H. and Tallman, S. 1997, 'Control and Performance in International Joint Ventures', Organization Science, 8 (3): 257-74.

Pangarkar, N. and Klein, S. 2004, 'The Impact of Control on International Joint Venture Performance: A Contingency Approach', Journal of International Marketing, 12 (3): 86-107.

Parkhe, A. 1993, 'Strategic Alliance Structuring: A Game Theoretic and Transaction Cost Examination of Interfirm Cooperation', Academy of Management Journal, 36 (4): 794-829.

Perlmutter, H.V. and Heenan, D.A. 1986, 'Cooperate to Compete Globally', Harvard Business Review, 64 (2): 136-52.

Schaan, J.L. and Beamish, P.W. 1988, 'Joint Venture General Managers in LDCs', in Contractor F.J. and Lorange, P., Cooperative Strategies in International Business: Joint ventures and Technology Partnerships between Firms, Lexington Books, Lexington.

Schaan, J.L., 1988, 'How to Control a Joint Venture Even as a Minority Partner', Journal of General Management, 14 (1): 4-16.

Schillaci, E. 1988, Profili Economico Aziendali della Formula Joint Venture, Giuffre Editore, Milan.

Seth, A. 1990, 'Value Creation in Acquisitions: A Re-examination of Performance Issues', Strategic Management Journal, 11 (2): 99-115.

Shenkar, O. and Tallman, S.B. (1993), 'Formation of International Cooperative Ventures: An Organizational Perspective’, Advances in International Comparative Management, 8: 101-17.

Southworth, A. 1994, ‘Accounting For East-West Joint Ventures: Tambrands’ Experience in the Ukraine’, Management Accounting Research, 5 (2): 167-84.

Wakefield, J. and Giacobbe, F. 2008, 'The Implications of Motive Divergence on International Joint Venture Management Controls Systems and Performance', unpublished paper presented at AFAANZ Conference, July.

Yan, A. and Gray, B. 1994, 'Bargaining Power, Management Control, and Performance in United States - China Joint Ventures: A Comparative Case Study', Academy of Management Journal, 37 (6): 1478-517.

Yan, A. and Gray, B. 2001, 'Antecedents and Effects of Parent Control in International Joint Ventures’, Journal of Management Studies, 38 (3): 393-416. 